引用格式: 董佳静, 赵昒, 王重阳, 等. 1980-2016年北京市食物消费的土地需求 [J]. 资源科学, 2019, 41(7): 1350-1358. [Dong J J, Zhao Y, Wang C Y, et al. Land demands for food consumption in Beijing during 1980-2016[J]. Resources Science, 2019, 41(7): 1350-1358.] DOI: 10.18402/resci.2019.07.15

\title{
1980-2016 年北京市食物消费的土地需求
}

\author{
董佳静 ${ }^{1}$, 赵 旸 ${ }^{1}$, 王重阳 ${ }^{1}$, 肖 潚 ${ }^{1}$, 张 丹 $^{2}$, 刘立涛 ${ }^{2}$, \\ 刘晓洁 ${ }^{2}$, 张亚丽 $^{2}$,伦飞 1
}

(1. 中国农业大学土地科学与技术学院, 北京 100193 ;

2. 中国科学院地理科学与资源研究所, 北京 100101)

\begin{abstract}
摘 要: 社会经济发展和居民食物消费对土地需求之间的矛盾, 已成为中国可持续发展亟待解决的关键问题, 也是当今社会关注的热点问题之一。然而, 目前对城市尺度食物消费的土地需求研究仍存在不足。本文利用 CPI 指数法,估算了北京市城乡居民1980-2016年的食物消费情况,揭示了居民食物消费结构改变对土地需求的演变特 征, 并探讨了未来不同消费模式下的土地需求情况, 以期为实现居民的可持续消费提供参考, 从而更好地解决社会 经济发展和居民食物消费对土地需求之间的矛盾。结果表明: 北京市食物消费结构已经由“粮食主导”的消费模式逐 渐变为多元化的消费模式，且城乡之间存在明显差异; 1980-2016年,北京市居民人均食物消费的土地需求量呈“U” 型的变化特征, 其中粮食消费的土地需求不断减少, 而蔬果和动物性食物的土地需求不断增加; 在 2016 年, 北京市 居民人均食物消费的土地需求量达到了 $1227.04 \mathrm{~m}^{2}$ /人, 使得北京市居民消费的土地需求总量达到了 266.62 万 $\mathrm{hm}^{2}$, 其中动物性食物消费占 $70.36 \%$, 城市居民食物消费占 $95 \%$ 以上; 在 2016 年, 北京市居民食物消费的土地需求压力 达到了 14 。健康合理的食物消费结构不仅有利于身体健康, 也能够缓解食物消费对土地资源的压力; 在健康饮食 情景下, 北京市每年居民食物消费最多可节约 $95.20 ~ 153.32$ 万 $\mathrm{hm}^{2}$ 的土地面积, 相当于北京市现有耕地和果园面积 的 5 8 倍。因此, 通过合理的饮食结构调整对解决社会经济发展和居民食物消费对土地需求之间的矛盾具有重要的 意义。
\end{abstract}

关键词: 食物消费; 土地需求; 土地压力;CPI指数法;粮食安全;饮食结构

DOI :10.18402/resci.2019.07.15

\section{1 引言}

粮食安全是国家战略安全的重要组成部分,也 关系着社会稳定和经济发展 ${ }^{[1]}$ 。然而, 全球粮食安 全问题仍十分严重, 2015 年全球仍有 7.95 亿人的食 物消费得不到满足, 处于营养不良的状态 ${ }^{[2]}$ 。因此, 如何更好地保障粮食安全, 已经成为各国 21 世纪亟 需解决的关键问题。土地资源 (尤其是耕地资源) 是人类赖以生存的基础, 其在一定程度上影响着国 家的粮食安全 ${ }^{[3]}$ 。因此, 明确人类食物消费所需的 土地面积, 对于更好地解决国家粮食安全问题具有
重要的意义和价值, 这已成为全球关注的热点 ${ }^{[4-6]}$ 。 中国作为世界上人口最多的国家,耕地资源有 限, 人均耕地面积仅为全球人均耕地面积的一半 ${ }^{[7]}$, 耕地资源的有限性在一定程度上制约着中国粮食 安全问题 ${ }^{[8,9]}$ 。科技水平和生产效率的提高, 在一定 程度上缓解了中国粮食安全问题;然而,近年来工 业化和城市化进程的加快, 对中国耕地资源造成了 严重的威胁,进而影响着中国的粮食安全 ${ }^{[10,11]}$ 。与此 同时, 中国居民动物性食物消费逐渐增加, 也进一 步加剧了居民食物消费对土地资源的压力 ${ }^{[12,13]}$, 且

收稿日期: 2019-01-02, 修订日期: 2019-03-21

基金项目: 国家重点研发计划项目(2018YFA0606303); 国家自然科学基金项目(41801202;41601602)。

作者简介: 董佳静, 女, 内蒙古集宁人, 硕士生, 研究方向为土地生态。E-mail: 787426488@qq.com

通讯作者: 伦飞, 男, 山东淮坊人, 博士, 副教授, 研究方向为土地资源管理。E-mail: lunfei@cau.edu.cn 
呈现日趋加剧的趋势。如何解决社会经济发展和 居民食物消费对土地需求之间的矛盾, 已成为中国 可持续发展吕待解决的关键问题之一 ${ }^{[14]}$ 。

因此, 厘清居民食物消费结构变化, 揭示其对 土地需求的演变特征, 有利于解决社会经济发展和 居民食物消费对土地需求之间的矛盾, 对于实现国 家资源有效配置和可持续发展具有重要的现实意 $义^{[15]}$ 。目前, 对于居民食物消费的土地需求研究, 主 要是基于 Gerbens-Leenes 等 ${ }^{[16]}$ 和 Kastner 等 ${ }^{[17]}$ 提出的 “虚拟土地” 的概念, 即通过食物消费量及其土地生产 效率得到土地需求量, 其中食物的土地生产效率是 指单位土地生产某种食物的数量。基于“虚拟土 地”的概念, 国内外学者对食物消费的土地需求开展 了大量的研究,包括从饮食结构 ${ }^{[18-20]}$ 、人口规模 ${ }^{[21,22]}$ 、 城乡结构 ${ }^{[23,24]}$ 等角度对食物消费的土地需求。目 前, 居民食物消费的土地需求研究主要集中在国家 尺度上, 缺乏从城市尺度探求食物消费变化对土地 需求及其压力的影响。因此, 本文以北京市为例, 基于不同食物类型的“虚拟土地”结果, 探讨了长期 食物消费结构的改变对土地需求及其压力的演变 特征情况, 以期更好地解决土地需求存在的矛盾 问题。

中国地域辽阔, 不同地区之间的自然环境、经 济发展、饮食文化等方面存在较大差异, 研究城市 居民食物消费结构变化及其对土地需求演变特征, 对于更好优化城市土地有效配置和实现粮食安全 具有重要的作用 ${ }^{[25,26]}$ 。北京是中国的政治、经济、文 化中心, 社会经济发展水平不断提高, 城市面积不 断扩张, 到 2016 年城市化率达到了 $86.4 \%{ }^{[27]}$, 耕地面 积逐年下降且破碎化程度日趋严重 ${ }^{[28,29]}$; 与此同时, 北京市人口数量和居民饮食结构的变化, 进一步加 剧了北京市居民消费对土地的需求 ${ }^{[30]}$ 。因此, 明确 北京市居民食物消费结构变化及其对土地需求的 影响, 对于更好地解决北京市经济发展与耕地保护 之间的矛盾, 具有重要的现实意义 ${ }^{[31,32]}$ 。因此, 本文 利用 CPI 指数法,估算了北京市城乡居民 19802016 年的食物消费情况,并基于虚拟土地的方法, 估算了居民食物消费对土地需求的演变特征, 从而 探讨了未来不同消费模式下的土地需求情况,以期 为居民的可持续消费提供参考。

\section{2 数据与方法}

\section{1 数据来源与处理}

本文的数据包括不同食物的生产和消费数据, 以及人口数据, 其中: 1) 1980-2000年的城乡居民人 均食物消费数据来源于《北京统计年鉴》 ${ }^{[33]}$, 由于缺少 2000 年之后的城镇居民人均食物消费量数据, 故 2000-2016年城镇居民的人均食物消费量利用 2000 年的相关数据并结合 CPI 指数迭代推算得到 ${ }^{[34]}$; 2 不同农作物的产量及面积数据来自于中华人民共 和国农业农村部 (http://www.moa.gov.cn); (3)人数 据来自于《北京统计年鉴》 ${ }^{[33]}$,其主要是指年末常住 人口数,包括城镇人口和农村人口。此外, 膳食平 衡数据来自于《中国居民膳食指南》 ${ }^{[35]}$, 北京市 $2030 、 2050$ 年的人口数据是基于 Logistic 模型, 在高 生育率 (大于 2.0 ) 条件下推算得到的 ${ }^{[36]}$, 而动物性食 物的料肉比数据则是根据唐华俊等 ${ }^{[37]}$ 、田甜等 ${ }^{[3]}$ 的 研究, 取其平均值计算得到。

\section{2 研究方法}

\subsection{1 食物消费量}

本研究利用 CPI 指数 ${ }^{[34]}$, 以 2000 年的城镇居民 食物消费量和消费额为基准,迭代计算了北京市 2001-2016年城镇居民的食物消费量。具体计算 公式如下:

$$
Q_{i, j+1}=\frac{Q_{i, j} \times C_{i, j+1}}{C_{i, j} \times C P I_{j+1}}
$$

式中: $C_{i, j}$ 为第 $i$ 类食物第 $j$ 年的消费额; $Q_{i, j}$ 为第 $i$ 类 食物第 $j$ 年的消费量。

根据式 (1), 经逐年迭代推算出 2001-2016年 北京市的城镇居民食物消费量, 与农村居民的相应 类别的食物消费量, 便可得到北京市居民食物消费 的总量。

\subsection{2 食物消费土地需求量}

为了便于分析,本研究将食物分为两大类:(1) 植 物性食物,包括粮食 (谷物、薯类和豆类)、蔬菜和水 果; (2)动物性食物,包括肉类(猪/牛/羊肉、禽类)、蛋 奶及水产品类 (蛋类、奶及奶制品、水产品)。不同 食物消费的土地需求量计算方法如下:

基于“虚拟土地”的概念, 居民食物消费量与生 产单位食物所需土地面积的乘积即为其食物消费 的土地需求量, 其中生产单位植物性食物所需的土 
地可以通过其单产进行计算, 而生产单位动物性食 物所需要的土地则通过粮食产量及料肉比进行估 算; 根据相关学者的研究 ${ }^{[13,14,23,35]}$, 本文采用的猪肉、 牛羊肉、禽肉、蛋类、奶类及水产品的料肉比 $\left(G_{i}\right)$ 分 别为 $4.3 、 2.6 、 2.6 、 0.5$ 和 0.5 , 具体计算过程见公式 (2)、(3)。

$$
\begin{gathered}
L R P_{\mathrm{p}}=\sum_{i=0}^{n} \frac{F_{i}}{Y_{i}} \\
L R P_{\mathrm{L}}=\sum_{i=0}^{n} \frac{F_{i} \times G_{i}}{Y_{i}}
\end{gathered}
$$

式中: $L R P_{\mathrm{P}}$ 和 $L R P_{\mathrm{L}}$ 为人均植物性和动物性食物消费 的土地需求量 $\left(\mathrm{m}^{2} /\right.$ 人); $F_{i}$ 为第 $i$ 类食物的人均消费 量; $Y_{i}$ 为第 $i$ 类食物单位土地面积产量; $i 、 n$ 为居民消 费的食物种类和数量; $G_{i}$ 为料肉比。

\subsection{3 食物消费对现有土地资源的压力}

本文将食物消费的土地需求分为耕地需求 (粮 食、蔬菜、动物性食物类) 和果园需求 (水果类), 并 与北京市现有耕地、果园面积相比(公式(4))。若 比值大于 1 , 说明该地区现有土地资源可以供给其 居民食物消费; 若比值小于 1 , 则说明该地区现有土
地资源不能满足其居民现阶段的饮食结构需求, 且 比值越小,其对外依赖程度较高。

$$
I_{x}=\frac{T_{x}}{N_{x}}
$$

式中: $I$ 为食物消费对现有土地资源的压力值; $T$ 为 食物消费土地需求面积; $N$ 为现有土地面积; $x$ 为不 同土地类型。

\section{3 结果与分析}

\section{$3.11980-2016$ 年北京市居民饮食结构变化}

北京市居民食物消费结构大体可分为两个阶段, 具体情况如下: 在 1980-1995年间,随着中国改革开 放和北京市社会经济的发展, 其居民食物消费结构 逐渐由“粮食为主”转向“多元化消费”, 但受到经济 发展水平的制约, 蔬果类和动物性消费的增长较为缓 慢 ${ }^{[39,40]}$, 而人均粮食消费下降明显, 约下降了 $47.23 \%$, 且城乡居民的差距相对较小(图 1)。在 1996-2016 年间, 随着社会经济的进一步发展, 居民生活水平 不断提高 ${ }^{[4]}$, 北京市居民食物消费结构进一步向多 元化发展, 其人均蔬果类和动物性消费迅速增加, 至 2016 年, 分别达到 $737.31 \mathrm{~kg} /$ 人和 $225.54 \mathrm{~kg} /$ 人。与
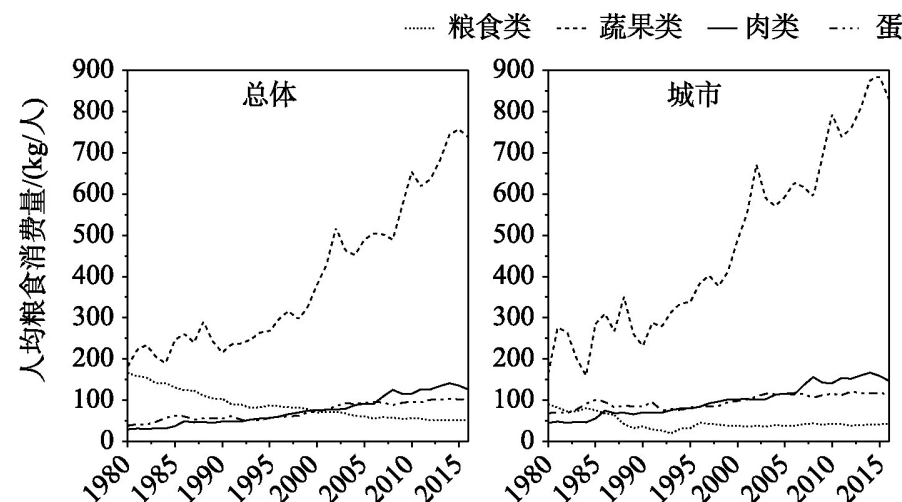

蛋奶及水产品
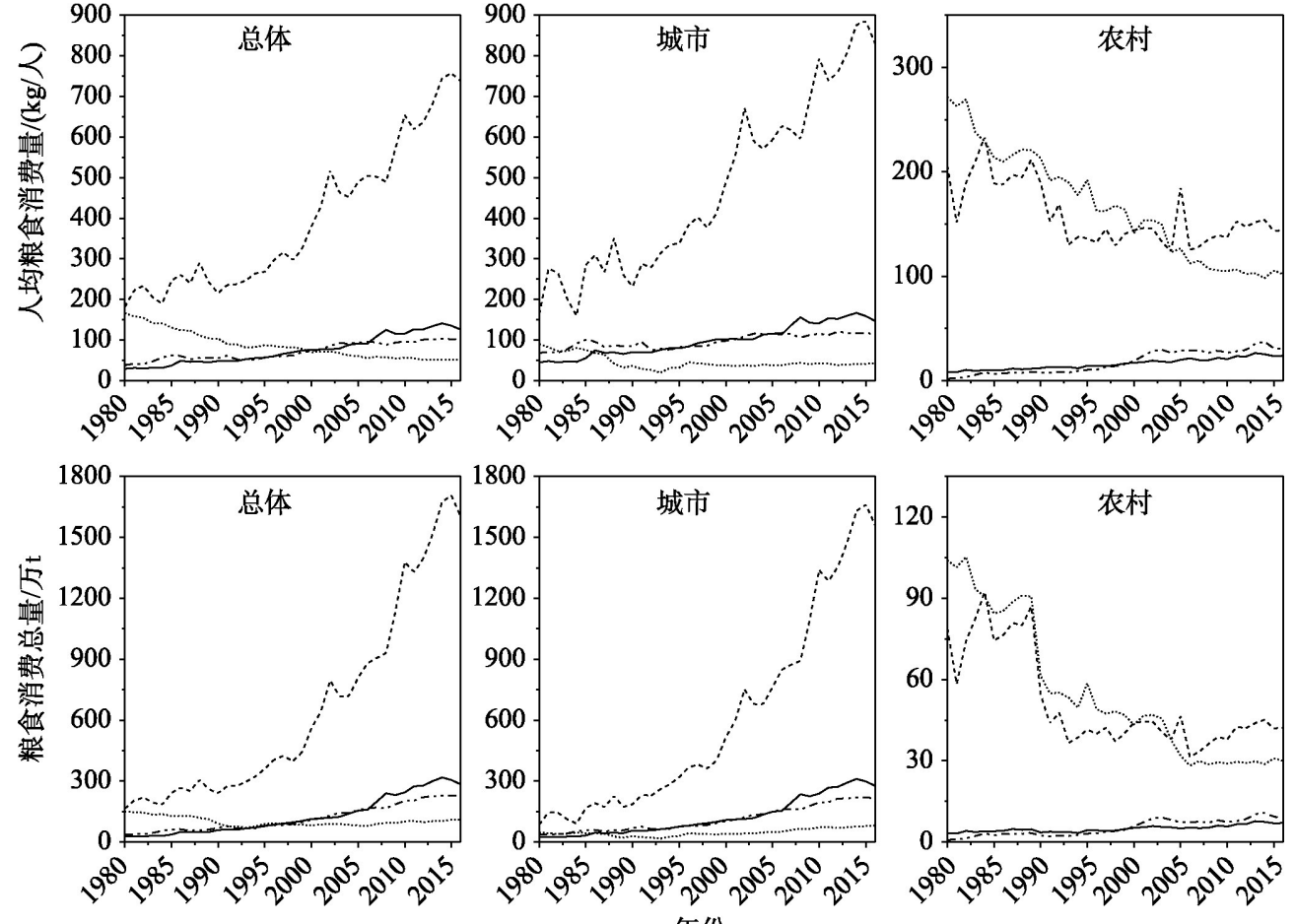

年份

图 11980 -2016 年北京市居民食物消费情况

Figure 1 Human food consumption in Beijing, 1980-2016 
此同时, 由于城乡居民收人差距的进一步扩大 ${ }^{[33]}$, 使 得城乡居民的食物消费结构存在较大差异, 尤其是 蔬果类和动物性食物的消费。2016年, 城市居民的 人均蔬果和肉类消费量约为农村居民人均消费的 5 倍左右, 且北京市 $95.96 \%$ 的蛋奶及水产品消费来自 于城市居民。

\section{2 北京市人均食物消费的土地需求}

食物消费的土地需求是由食物消费量、食物消 费结构和土地生产效率决定的 ${ }^{[4,17]}$ 。在 1980-2016 年间, 北京市居民的食物消费逐渐转向蔬果和动物 性食物消费为主, 蔬果和动物性食物消费量增加迅 速, 这在一定程度上增加了对土地需求的压力。然 而,随着北京市农业基础设施的完善和农业科技水平 的提高,农业生产效率得到较大提升, 北京市 2016 年粮食单位面积产量约为 1980 年的 1.81 倍, 这在一 定程度上减缓了食物消费对土地需求的压力 ${ }^{[19]}$ 。综 合上述影响因素, 北京市人均食物消费的土地需求 在 1980-2016 年间呈现明显的“U”型特征(图 2)， 且由 “以粮食消费主导”逐渐变为 “以动物性消费为 主导”, 其中:在 1995 年之前, 北京市人均食物消费 的土地需求量由粮食消费主导, 随着粮食消费的迅 速减少, 其人均食物消费土地需求量下降了 $25.12 \%$
( $250.81 \mathrm{~m}^{2} /$ 人), 其中人均粮食消费的土地需求量由 $492.21 \mathrm{~m}^{2} /$ 人迅速下降到 $147.15 \mathrm{~m}^{2} /$ 人; 在 1995 年之 后, 北京市人均食物消费的土地需求则以动物性食 物消费为主, 2016 年达到了 $1227.04 \mathrm{~m}^{2} /$ 人, 其中人 均肉类消费的土地需求增加最为显著, 增加了 $310.46 \mathrm{~m}^{2}$ /人。由于食物消费结构的差异, 使得北京 市城乡居民食物消费的土地需求呈现出不同的特 征,其中:城市居民人均食物消费的土地需求量也呈 “U”型特征, 2016 年达到 $1350.69 \mathrm{~m}^{2} /$ 人, 动物性食物 消费占 $71.57 \%$, 而粮食和蔬果消费的土地需求量则 分别为 $70.53 \mathrm{~m}^{2} /$ 人和 $313.40 \mathrm{~m}^{2} /$ 人; 北京市农村居民 人均食物消费的土地需求呈不断下降的趋势, 在 1980-2016年间下降了 54.94\%, 这主要是因为农村 居民食物消费仍以粮食为主且消费量不断下降,而 其他食物消费增加相对较少, 此外, 北京市农村居 民食物消费的土地需求在 2003 年之前由粮食消费 主导, 而在 2008 年之后则由动物性食物消费为主 导;在 2016年,北京市农村居民粮食、蔬果和动物性 食品消费的土地需求分别为 $166.07 、 67.53$ 和 201.37 $\mathrm{m}^{2} /$ 人。

\section{3 北京市食物消费土地需求总量}

北京市人均食物消费结构改变和人口的不断

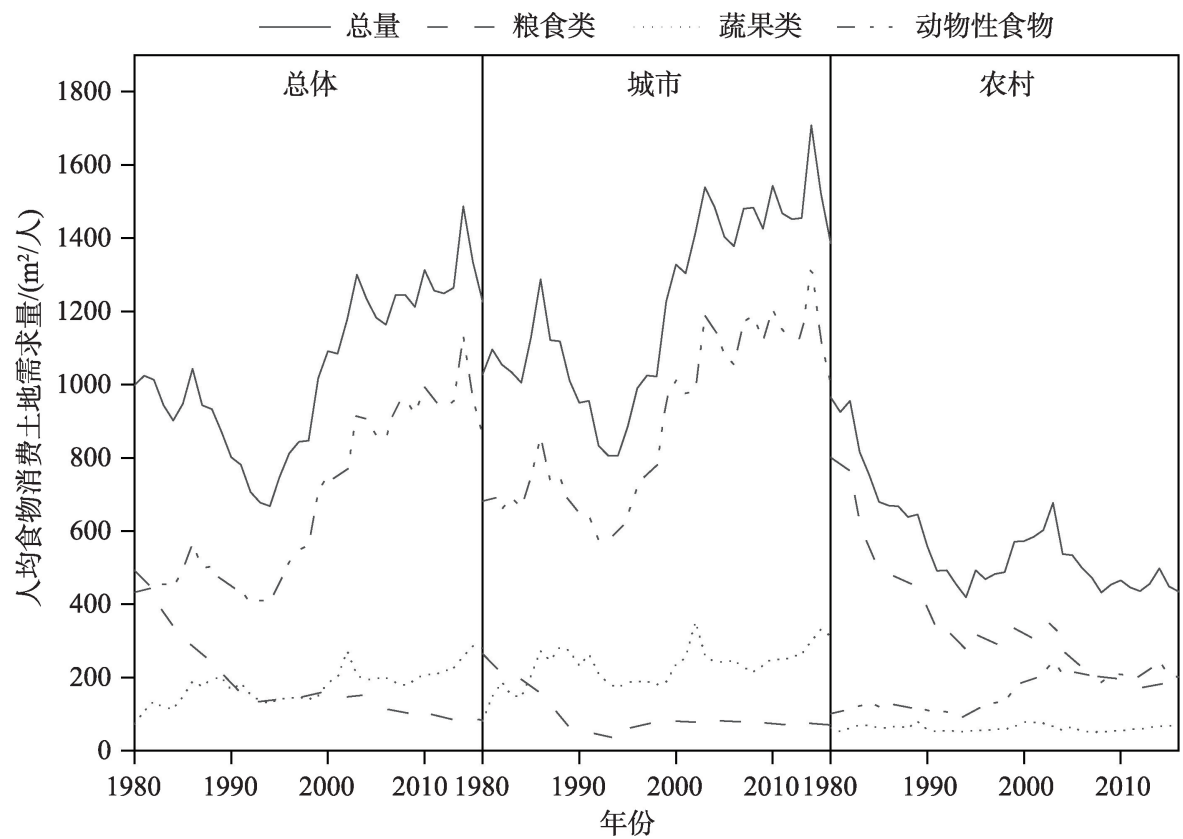

图 $21980-2016$ 年北京市居民人均食物消费的土地需求情况

Figure 2 Land demands per capita for food consumption in Beijing, 1980-2016 
增加, 使得其居民食物消费的土地需求量呈不断增 加趋势, 2016 年达到了 266.62 万 $\mathrm{hm}^{2}$, 其中 $74.37 \%$ 来自于动物性食物消费(图 3)。研究期内, 尽管北 京市人口增加, 但人均粮食消费量不断减少, 使得 北京市粮食消费的土地需求总量有所减少, 减少量 为 26.38 万 $\mathrm{hm}^{2}$, 但其他类型食物消费的增加, 使得 北京市食物消费的土地需求总量增加了 176.32 万 $\mathrm{hm}^{2}$, 其中蔬果类和动物性食物分别占 $22.84 \%$ 和 $70.37 \%$ 。随着北京市城市化进程的不断发展, 城市 人口迅速增加, 且食物消费结构不断升级, 使得北 京市城市居民食物消费的土地需求总量在 2016 年 时达到了 253.86 万 $\mathrm{hm}^{2}$, 其中动物性食物所占比重 达 $71.57 \%$, 而粮食消费的土地需求仅为 13.26 万 $\mathrm{hm}^{2}$ 。由于农村人口数量的下降和饮食结构的改 变, 使得北京市农村食物消费的土地需求总量不断 下降, 到 2016 年时仅为 12.76 万 $\mathrm{hm}^{2}$, 但粮食消费仍

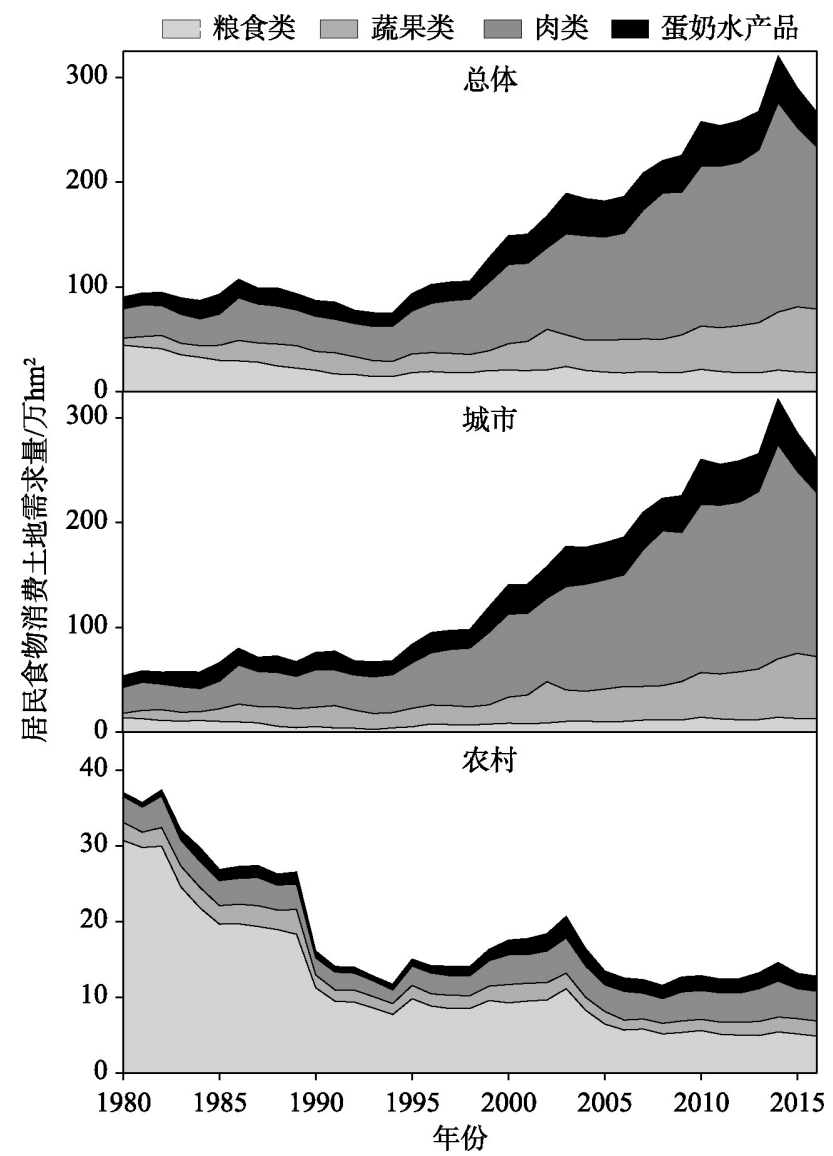

图 $31980-2016$ 年北京市居民食物消费的土地总需求情况

Figure 3 Total land demands for food consumption in Beijing, 1980-2016
相对较高, 所占比重达到了 $38.18 \%$, 远高于城市居 民粮食消费所占比重。北京市农村蔬果、肉类、蛋 奶及水产品消费的土地需求分别为 1.98 万 $\mathrm{hm}^{2} 、 3.93$ 万 $\mathrm{hm}^{2}$ 和 1.97 万 $\mathrm{hm}^{2}$ 。

\section{4 北京市居民食物消费土地需求的压力分析}

北京市居民食物消费的土地需求一直处于“供 小于求”的状态, 且 2000 年之后, 由于北京市的耕地 面积迅速减少,食物消费的土地需求缺口急剧扩大 （图4）。北京市 2016 年居民食物消费的土地需求压 力达到了 14 , 即大约需要 14 倍的现有耕地和果园面 积来满足其居民的食物消费。1 995 年之前, 北京市 居民食物消费的耕地压力相对稳定, 其压力大约为 1 2 之间; 1995 年之后, 动物性食物消费的增加和耕 地的减少,使得食物消费对耕地的压力迅速增大, 到 2016 年时, 北京市大约需要 18 倍的现有耕地面 积才能满足其粮食、蔬菜及动物性食物的消费。此 外, 北京市居民水果消费对其果园压力相对较小, 但仍呈 “供小于求” 的状态, 且日趋扩大。在 2016 年, 北京市居民的水果消费大约需要 5.5 倍的当年 果园面积来满足。由此可见,北京市居民食物消费 及其土地需求对外依赖十分严重。

\section{5 不同情境下北京市居民食物消费土地需求}

饮食结构和人口数量是影响居民食物消费土 地需求及其压力的重要因素。因此,本文探讨了不

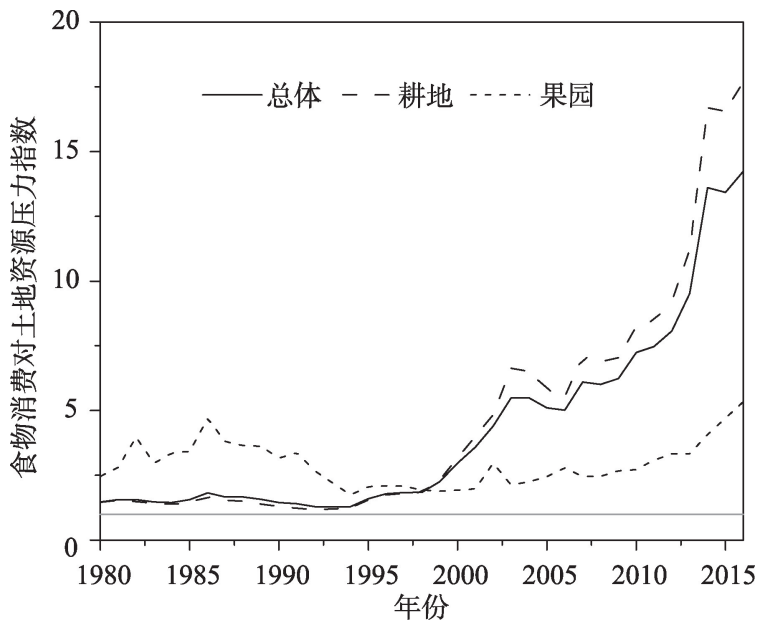

图 $41980-2016$ 年北京市食物消费的土地需求压力情况

Figure 4 Pressure of land demand for food consumption in Beijing, 1980-2016

注: 灰线表示为压力值为 1 , 即本地区供应等于本地区的消费; 若小 于 1 , 则为供应大于需求; 若大于 1 , 则为供应小于需求。 
同食物消费情景下的土地需求情况。目前北京市 正处于经济高速发展的阶段,饮食结构的营养转型 使得动物性食物消费逐渐增加, 但与《中国居民膳 食指南》所提出的膳食平衡宝塔相比较, 仍存在营 养过剩和营养不足的双重挑战。其中, 北京市居民 的猪肉消费过多, 但牛羊肉的消费相对较少, 而水 产品等高蛋白食物摄人严重不足。因此, 本文探讨 了健康饮食情景下的土地需求情况 (表 1)。以 2016 年为例, 北京市人均粮食类和奶类的土地需求量低 于健康饮食情景的土地需求, 但其他食物消费的土 地需求量均超过了健康饮食情景, 使得北京市居民 食物消费的土地需求远高于健康饮食下的土地需 求 (大约 1.7 2.6 倍), 尤其是肉类消费的土地需求 量。如果北京市居民能够采取健康饮食消费模式, 其2016年食物消费可节约95.20 153.32万 $\mathrm{hm}^{2}$ 的土 地资源, 相当于北京市 2016年耕地和果园面积的 5 8 倍。由此可见, 健康合理的饮食结构, 不仅有利于 居民身体健康，也有助于土地资源的可持续利用。

北京市居民人口的不断增加必然会加剧对自 然资源的压力, 据预测, 北京市人口在 2030 及 2050 年将分别达到 2300 万人和 2383 万人 ${ }^{[36]}$ 。在目前的 饮食结构下,2030年北京市食物消费的耕地需求将 增加 13.94 万 $\mathrm{hm}^{2}$ (表 2), 超过北京市现有的耕地资 源, 且到 2050 年时, 北京市耕地需求的缺口将会持 续增大。如果未来采取更加合理的饮食结构, 在 2030 年时, 北京市居民食物消费可节省 134.88 万 $\mathrm{hm}^{2}$ 耕地面积和 7.26 万 $\mathrm{hm}^{2}$ 的果园面积。由此可见， 随着人口的不断增加, 合理的饮食结构对土地资源 的节约将会发挥重要的作用。

表 1 不同情境下北京市 2016 年食物消费的土地需求情况

Table 1 Land demands for food consumption in Beijing in 2016 under different scenarios

$\left(\right.$ 万 $\left.\mathrm{hm}^{2}\right)$

\begin{tabular}{lcc}
\hline & $\begin{array}{c}\text { 目前情景下的 } \\
\text { 土地需求量 }\end{array}$ & $\begin{array}{c}\text { 膳食宝塔建议下的 } \\
\text { 土地需求量 }\end{array}$ \\
\hline 粮食类 & 18.1 & $35.9 \sim 57.4$ \\
蔬菜 & 32.9 & $6.6 \sim 10.9$ \\
水果 & 28.1 & $11.2 \sim 19.6$ \\
肉类 & 154.5 & $19.8 \sim 37.1$ \\
蛋类 & 19.0 & $15.5 \sim 19.4$ \\
奶及奶制品 & 8.3 & 21.5 \\
水产品 & 5.9 & $2.9 \sim 5.4$ \\
总体 & 266.62 & $113.3 \sim 171.4$ \\
\hline
\end{tabular}

表 2 不同情境下北京市 2030 年和 2050 年居民 食物消费的土地需求情况

Table 2 Land demands for food consumption in Beijing in 2030 and 2050 under different scenarios

$\left(\right.$ 万 $\left.\mathrm{hm}^{2}\right)$

\begin{tabular}{lccccc}
\hline & \multicolumn{2}{c}{2030 年 } & & \multicolumn{2}{c}{2050 年 } \\
\cline { 2 - 3 } \cline { 5 - 6 } & $\Delta_{1}$ & $\Delta_{2}$ & & $\Delta_{1}$ & $\Delta_{2}$ \\
\hline 粮食 & 1.06 & 28.78 & & 1.74 & 30.45 \\
蔬菜 & 1.92 & -26.42 & & 3.16 & -26.19 \\
水果 & 1.64 & -7.26 & & 2.7 & -6.51 \\
肉类 & 9.03 & -145.28 & & 14.86 & -144.95 \\
蛋类 & 1.11 & -3.09 & & 1.83 & -2.52 \\
奶及奶制品 & 0.48 & 13.39 & & 0.8 & 14.17 \\
水产品 & 0.34 & -2.26 & & 0.56 & -2.13 \\
耕地 & 13.94 & -134.88 & & 22.95 & -131.18 \\
压力值 & 1.04 & -10 & & 1.7 & -9.73 \\
果园 & 1.64 & -7.26 & & 2.7 & -6.51 \\
压力值 & 0.31 & -1.38 & 0.51 & -1.25 \\
\hline
\end{tabular}

注: $\Delta_{1} 、 \Delta_{2}$ 分别等于基于 2016 年的饮食结构和膳食宝塔饮食 结构计算出的土地需求量差量。

\section{4 结论与建议}

\section{1 结论}

本文对 1980-2016年北京市居民食物消费的 土地需求及其压力进行了研究, 并探讨了饮食结构 改变和人口增加对土地需求的影响,主要结论如下：

(1) 在改革开放及经济快速增长的背景下, 北 京市居民食物消费逐步多元化, 人均粮食消费逐年 下降,而蔬果和动物性食物消费不断增加; 北京市 城乡收人差距使得其食物消费结构存在一定的差 异, 其中城市居民的动物性食物消费相对较多, 而 农村居民粮食消费相对较多。

（2）食物消费结构的改变和单位面积产量的提 高, 使得北京市居民人均食物消费的土地需求在 1980-2016年呈“U”型变化特征,由粮食主导逐渐变 为动物性食物主导。动物性食物消费的土地需求量 为全国平均水平的 4 倍左右, 而粮食消费则低于全 国水平; 城市居民人均食物消费的土地需求也呈 “U”型变化特征,但农村居民人均食物消费的土地 需求则呈不断下降趋势, 这主要是由粮食消费下降 引起的。

(3)人口的增加和食物消费结构的改变,使得 北京市居民食物消费的土地需求总量不断增加, 动 物性食物消费占 $70.36 \%$, 城市居民食物消费占 $95 \%$ 
以上。与此同时, 北京市耕地面积不断减少, 使得 其土地需求压力不断增加, 在 2016 年, 北京市需要 14 倍的当年耕地面积和当年果园面积来满足本地 居民食物消费。

（4）合理的饮食结构不仅有利于身体健康, 还 能够有效地减少居民食物消费对土地资源的压力， 尤其是未来人口不断在增加的状况, 其缓解作用尤 其显著。

\section{2 建议}

基于上述研究,本文提出了如下的政策建议:

(1) 北京市不合理的饮食结构, 不仅在一定程 度上造成了土地资源的压力, 还对居民健康产生一 定的影响, 因此, 应积极倡导更加合理、健康、营养 的饮食模式, 减少肉类消费, 增加奶类、粮食类等摄 人量, 在平衡瞨食的范围内减缓土地供给压力。

(2) 应坚守耕地数量、质量指标, 严格执行城市 用地规模审核制度, 同时引进农田科技设施, 提高 粮食、蔬果类的单产效率, 以提升北京市食物自给 能力, 减少其食物消费对外依赖程度。

本文由于部分数据的缺失, 对于北京市居民食 物消费的分析仍存在一定的不足, 未考虑大量流动 人口对食物消费结构及土地需求的影响, 未来需要 对此进行更深人的研究与探讨。同时, 本文对于动 物性食物消费的土地需求, 主要是通过料肉比进行 估算, 并未探讨草原的土地利用情况, 在未来研究 中需要对此进行进一步探讨与分析。

\section{参考文献(References):}

[1] 陈源源, 吕昌河, 尚凯丽. 食物安全的内涵、指标与评价方法综 述[J]. 中国农学通报, 2017, 33(22): 158-164. [Chen Y Y, Lv C

H, Shang K L. A review on concept, indicators and evaluation methods of food security[J]. Chinese Agricultural Science Bulletin, 2017, 33(22): 158-164.]

[2] WFP, FAO, IFAD. The State of Food Insecurity in the World 2015 [R]. Rome: FAO, 2015.

[3] 欧胜彬, 苏雪华. 粮食安全: 耕地质量保护是关键[J]. 农业经 济, 2012, (8): 54-56. [Ou S B, Su X H. Cultivated land quality protection is the key to food security[J]. Agricultural Economy, 2012, (8): 54-56.]

[4] Alexander P, Rounsevell A, Dislich C, et al. Drivers for global agricultural land use change: The nexus of diet, population, yield and bioenergy[J]. Global Environment Change, 2015, 35: 138-147.
[ 5] Eshel G, Shepon A, Makov T, et al. Land, irrigation water, greenhouse gas, and reactive nitrogen burdens of meat, eggs, and dairy production in the United States[J]. Proceedings of the National Academy of Sciences of the United States of America, 2014, 111 (33): 11996-12001.

[6] Audsley E, Angus A, Chatterton J, et al. The Effect of Changes in UK Food Consumption on Land Requirements and Greenhouse Gas Emissions[R]. Bedford: A Report Prepared for the United Kingdom's Committee on Climate Change, 2010.

[7] 刘丹, 巩前文, 杨文杰. 改革开放 40 年来中国耕地保护政策演 变及优化路径[J]. 中国农村经济, 2018, (12): 37-51. [Liu D, Gong Q W, Yang W J. The evolution of farmland protection policy and optimization path from 1978 to 2018[J]. Chinese Rural Economy, 2018, (12): 37-51.]

[8] 聂英. 中国粮食安全的耕地贡献分析[J]. 经济学家, 2015, (1): 83-93. [Nie Y. Analysis of cultivated land contribution to food security in China[J]. Economist, 2015, (1): 83-93.]

[9] Fan M, Shen J, Yuan L, et al. Improving crop productivity and resource use efficiency to ensure food security and environmental quality in China[J]. Journal of Experimental Botany, 2012, 63(1): 13-24.

[10] 付恭华, 鄢帮有. 中国未来的粮食安全与生态可持续性问题研 究: 基于粮食生产过程生态足迹的实证分析 [J]. 长江流域资源 与环境, 2013, 22(12): 1550-1556. [Fu G H, Yan B Y. Food security and ecological sustainability in China: An empirical analysis based on the ecological footprint of food production[J]. Resources and Environment in the Yangtze Basin, 2013, 22(12): 1550-1556.]

[11] 蔡雪雄, 李倩. 中国粮食主销区的粮食生产安全问题研究[J]. 亚 太经济, 2018, (5): 130-136. [Cai X X, Li Q. Research on food production safety in the main grain area of China[J]. Asia-pacific Economic Review, 2018, (5): 130-136.]

[12] Alexander P, Brown C, Arneth A, et al. Human appropriation of land for food: The role of $\operatorname{diet}[J]$. Global Environmental Change, 2016, 41: 88-98.

[13] 刘春霞, 王芳. 基于居民食物消费模式的中国耕地需求动态变 化分析[J]. 中国生态农业学报, 2018, 26(8): 1227-1235. [Liu C $\mathrm{X}$, Wang F. Dynamic changes in arable land requirements for food consumption in China[J]. Chinese Journal of Eco-Agriculture, 2018, 26(8): 1227-1235.]

[14] 赵姚阳, 蒋琳琳, 王洁. 居民膳食结构变化对中国食物生产用地 需求的影响研究 [J]. 中国人口・资源与环境, 2014, 24(3): 5460. [Zhao Y Y, Jiang L L, Wang J. Study of the effect of residents dietary pattern change to the land requirements for food[J]. China Population, Resources and Environment, 2014, 24(3): 54-60.]

[15] 曹淑艳, 谢高地. 城镇居民食物消费的生态足迹及生态文明程 度评价 [J]. 自然资源学报, 2016, 31(7): 1073-1085. [Cao S Y, Xie G D. Footprint and degree of ecological civilization assessment of Chinese urban food consumption[J]. Journal of Natural Resources, 2016, 31(7): 1073-1085.]

[16] Gerbens-Leenes P W, Nonhebel S, Cleveland C J. Consumption 
patterns and their effects on land required for food[J]. Ecological Economics, 2002, 42(1): 185-199.

[17] Kastner T, Rivas M J I, Koch W, et al. Global changes in diets and the consequences for land requirements for food[J]. Proceedings of the National Academy of Sciences of the United States of America, 2012, 109(18): 6868-6872.

[18] 张少春, 闵师, 马瑞. 城市化、食物消费转型及其生态环境影响 [J]. 城市发展研究, 2018, 25(3): 13-20. [Zhang S C, Min S, Ma R. Urbanization, food consumption transformation and its impact on ecological environment[J]. Urban Development Studies, 2018, 25 (3): 13-20.

[19] 许月卿, 吴艳芳, 张衍毓, 等. 从食物消费需求角度谈中国土地 利用战略[J]. 中国土地科学, 2011, 25(6): 24-29. [Xu Y Q, Wu Y F, Zhang Y Y, et al. Study on land use strategies in China from the viewpoint of food consumption[J]. China Land Science, 2011, 25 (6): 24-29.]

[20] 孙廷艳, 唐增, 尚振艳. 庆阳市食物消费结构与土地资源需求 [J]. 草业科学, 2015, 32(9): 1518-1523. [Sun T Y, Tang Z, Shang Z Y. The requirements for land resources based on food consumption patterns: A case study in Qingyang[J]. Pratacultural Science, 2015, 32(9): 1518-1523.]

[21] 封志明. 中国未来人口发展的粮食安全与耕地保障[J]. 人口研 究, 2007, 31(2): 15-29. [Feng Z M. Future food security and arable land guarantee for population development in China[J]. Population Research, 2007, 31(2): 15-29.]

[22] 刘宁. 人口结构、食物消费差异对中国粮食需求的影响[J]. 兰州 学刊, 2015, (11): 164-170. [Liu N. The impact of population structure and food consumption differences on food demand of China[J]. Lanzhou Academic Journal, 2015, (11): 164-170.]

[23] 田甜, 唐增, 孙廷艳. 中国不同地区食物消费对土地资源需求的 影响研究[J]. 草业学报, 2017, 26(2): 53-60. [Tian T, Tang Z, Sun T Y. Land requirements for food in different regions of China [J]. Acta Prataculturae Sinica, 2017, 26(2): 53-60.]

[24] 高利伟, 徐增让, 成升鬼, 等. 农村居民食物消费结构对耕地需 求的影响: 以西藏“一江两河”流域为例 [J]. 自然资源学报, 2017, 32(1): 12-25. [Gao L W, Xu Z R, Cheng S K, et al. Arable land requirements related food consumption pattern: A case study in Lhasa, Xigaze and Shannan region of rural Tibet[J]. Journal of Natural Resources, 2017, 32(1): 12-25.]

[25] 熊啨, 王东阳. 居民食物消费特征及影响因素分析: 基于全国 20 省居民食物消费调研[J]. 中国食物与营养, 2017, 23(3): 4953. [Xiong L, Wang D Y. Residents' food consumption characteristics and influencing factors: Based on food consumption investigation in 20 provinces of China[J]. Food and Nutrition in China, 2017, 23(3): 49-53.]

[26] 刘璐璐, 宋戈, 黄善林, 等. 基于粮食安全的黑龙江省耕地压力 时空特征分析 [J]. 东北师大学报(自然科学版), 2018, 50(1): 138-143. [Liu L L, Song G, Huang S L, et al. Analysis on the spatial-temporal characteristics of cultivated land pressure in Hei- longjiang Province based on food security[J]. Journal of Northeast Normal University (Natural Science Edition), 2018, 50(1): 138-143.]

[27] 孙强, 蔡运龙, 王乐. 北京耕地流失的时空特征与驱动机制[J]. 资源科学, 2007, 29(4): 158-163. [Sun Q, Cai Y L, Wang L. Temporal spatial processes of farmland conversion and its driving mechanisms in Beijing[J]. Resources Science, 2007, 29(4): 158-163.]

[28] 罗晓雷. 北京市新型城镇化建设与耕地保护工作问题探讨[J]. 南方农业, 2018, 12(10): 55-57. [Luo X F. On new-type urbanization and farmland protection in Beijing[J]. South China Agriculture, 2018, 12(10): 55-57.]

[29] 张丹, 伦飞, 成升鬼, 等. 不同规模餐馆食物浪费及其氮足迹: 以 北京市为例[J]. 生态学报, 2017, 37(5): 1699-1708. [Zhang D, Lun F, Cheng $\mathrm{S} \mathrm{K}$, et al. The nitrogen footprint of different scales of restaurant food waste: A Beijing case study[J]. Acta Ecologica Sinica, 2017, 37(5): 1699-1708.]

[30] Cai J M, Guo H, Larissa M, et al. Urban food supply under constrained land resources in Beijing: Potential and optimization[J]. Journal of Resources and Ecology, 2012, 3(3): 269-277.

[31] 裴厦, 刘春兰, 谢高地, 等. 北京与津冀之间隐性土地资源流动 研究 [J]. 中国人口・资源与环境, 2016, 26(1): 97-104. [Pei S Liu C L, Xie G D, et al. Study on inter-regional transfer of embodied land resources between Beijing and Tianjin-Hebei[J]. China Population, Resources and Environment, 2016, 26(1): 97-104.]

[32] 刘菁华, 李伟峰, 周伟奇, 等. 权衡城市扩张、耕地保护与生态效 益的京津冀城市群土地利用优化配置情景分析[J]. 生态学报, 2018, 38(12): 4341-4350. [Liu J H, Li W F, Zhou W Q, et al. Scenario simulation balancing multiple objectives for optimal land use allocation of the Beijing-Tianjin-Hebei megaregion[J]. Acta Ecologoca Sinica, 2018, 38(12): 4341-4350.]

[33] 北京市统计局. 北京统计年鉴[M]. 北京: 中国统计出版社, 1980-2016. [Beijing Municipal Bureau of Statistics. Beijing Statistical Yearbook[M]. Beijing: China Statistical Publishing House, 1980-2016.]

[34] 陈文辉, 谢高地, 张昌顺, 等. 北京市消耗食物生态足迹距离[J]. 生态学报, 2016, 36(4): 904-914. [Chen W H, Xie G D, Zhang C $\mathrm{S}$, et al. The ecological footprint distance of food consumed in Beijing[J]. Acta Ecologica Sinica, 2016, 36(4): 904-914.]

[35] 中国营养学会. 中国居民膳食指南(2016)[M]. 北京: 人民卫生出 版社, 2016. [Chinese Society of Nutrition. Dietary Guidelines for Chinese Residents (2016) [M]. Beijing: People's Medical Publishing House, 2016.]

[36] 宋佩锋. 人口预测方法比较研究[D]. 合肥: 安徽大学, 2013 [Song P F. A Comparative Study on the Methods of Population Projection[D]. Hefei: Anhui University, 2013.

[37] 唐华俊, 李哲敏. 基于中国居民平衡膳食模式的人均粮食需求 量研究[J]. 中国农业科学, 2012, 45(11): 2315-2327. [Tang H J, Li Z M. Study on per capita grain demand based on Chinese reasonable dietary pattern[J]. Scientia Agricultura Sinica, 2012, 45 (11): 2315-2327.] 
[38] 李艳华, 张晓梅, 李炳军. 我国饲料用粮的系统动力学预测建模 [J]. 河南科学, 2012, 30(1): 127-130. [Li Y H, Zhang X M, Li B J. A forecasting model for China's feed grain demand based on system dynamics approach[J]. Henan Science, 2012, 30(1): 127-130.]

[39] 李效顺, 蒋冬梅, 市正富. 基于粮食安全视角的中国耕地资源盈 亏测算[J]. 资源科学, 2014, 36(10): 2057-2065. [Li X S, Jiang D M, Bian Z F. The surplus and deficit measurement of the cultivated land in China in the view of food security[J]. Resources Science, 2014, 36(10): 2057-2065.]

[40] 叶宏亮. 基于国内外耕地资源有效供给的中国粮食安全研究 [D]. 杭州: 浙江大学, 2013. [Ye H L. The Research of China's
Food Security Based on Effective Supply of Cultivated Land Resources[D]. Hangzhou: Zhejiang University, 2013.]

[41] 杨旺明, 栾一博, 杨陈, 等. 中国饮食所需耕地面积长时间尺度 变化研究[J]. 资源科学, 2013, 35(5): 901-909. [Yang W M, Luan Y B, Yang C, et al. Changes in the land requirements for food from 1961 to 2007 in China[J]. Resources Science, 2013, 35(5): 901-909.]

[42] 刘兵. 基于农户与消费者利益的农产品供应链整合研究[D]. 沈 阳: 沈阳农业大学, 2013. [Liu B. Study on Agricultural Products Supply Chain Integration Based in the Interests of the Peasants and Consumers: Fresh Fruits and Vegetables in China as an Example[D]. Shenyang: Shenyang Agricultural University, 2013.]

\title{
Land demands for food consumption in Beijing during 1980-2016
}

\author{
DONG Jiajing1', ZHAO Yang1', WANG Chongyang1', XIAO Xiao', ZHANG Dan², LIU Litao², \\ LIU Xiaojie ${ }^{2}$, ZHANG Yali ${ }^{2}$, LUN Fei ${ }^{1}$ \\ (1. College of Land Science and Technology, China Agricultural University, Beijing 100193, China; \\ 2. Institute of Geographic Sciences and Natural Resources Research, CAS, Beijing 100101, China)
}

\begin{abstract}
The contradiction between socioeconomic development and land demands for food consumption has become one of the key issues for sustainable development. However, there is a lack of studies on land demands for food consumption at the urban level. Therefore, this study used the CPI index method to estimate food consumption of urban and rural residents in Beijing during 1980-2016. Based on the concept of virtual land, it revealed land demands as well as pressures due to human dietary change. We also explored land demands for food consumption under different scenarios in the future. Our results are as follows: human food consumption in Beijing has changed to more vegetables, fruits, and livestock products, and there are obvious differences in food consumption of urban and rural residents. Land demands for food consumption presented a Ushaped trend during this period. The per capita land demand for meat, eggs and milk, vegetables, and fruits increased significantly, while land demands for cereals have been decreasing. In 2016, land demands per capita for food consumption amounted to $1227.04 \mathrm{~m}^{2} / \mathrm{a}$, resulting in the total land demands of $266.62 \times 10^{4} \mathrm{hm}^{2}$, with animal product consumption accounting for $70.36 \%$ and urban consumption accounting for more than 95\%; and the pressure index for land demands reached 14 . With a healthier diet, it could save $95.20 \times 10^{4} \sim 153.32 \times 10^{4} \mathrm{hm}^{2}$ of land, equivalent to $5 \sim 8$ times of present arable land area in Beijing. Thus, to some extent, a healthy food dietary structure could also alleviate the pressure of land demands for human food consumption.
\end{abstract}

Key words: food consumption; land demands; land pressure; CPI index method; food security; dietary structure 